\title{
The Impacts of Land Use Land Cover Dynamics on Land Management. The Case Study of Adama Zuria District, Oromia Region, Ethiopia
}

\author{
Dinku Shiferaw Jote ${ }^{1} \quad$ Getachew Haile Wondimu $^{2 *} \quad$ Lemi Elala Delata $^{3}$ \\ 1.Oromia Agricultural Research Institute, Addis Ababa, Ethiopia \\ 2.Department of Environmental Sciences, College of Natural and computational Science, Madda Walabu \\ University, Oromia Ethiopia \\ 3. Geospatial Information Institute, Addis Ababa, Ethiopia
}

\begin{abstract}
The surface of the earth is undergoing rapid land-use/land-cover (LULC) changes due to various socio-economic activities and natural phenomena. The aim of this research paper was to assess the impacts of the Land Use/Land Cover Changes (LU/LCC) on land management over the period 1989-2017 in the Adama Zuria District. Due to rapid population growth: the expansion of the settlement, agricultural expansion, illegal transaction of the land and degradation of natural resources are the most visible socio-economic and land management problem in the study area. The analysis result of the study showed that in 1989 most of the study area had been covered by farmland and shrub land. In the period between 1989 and 2017, cultivated land, plantation and settlement showed incremental changes by $(+72.78),(+10.16)$ and $(+48.95) \mathrm{km}^{2}$ respectively. While, shrub land and bare land decreased by $(-89.65)$ and $(-42.64) \mathrm{km}^{2}$, respectively. On the other hand, the socio-economic survey result reviled the above result, which showed that bare land and shrub land decreased, but, cultivated land, settlement and plantation increased in the specified time. Expansion of agricultural land, population growth and the associated demand for land were the major driving forces for the observed LU/LCC changes in the study area. The impacts of LU/LCC on land management were in term of environmental deterioration, problem related to land use planning (urban and rural), meaning expansion of the illegal settlement and tenure insecurity. Hence, land management practices, utilization of alternative energy sources and family planning education are some of the appropriate interventions to reduce this dramatic change.
\end{abstract}

Keywords: Remote Sensing, GIS, LU/LCC, land tenure, land management.

DOI: $10.7176 / \mathrm{JEES} / 11-5-01$

Publication date:May $31^{\text {st }} 2021$

\section{Introduction}

Land is the major natural resource on which economic, social, infrastructure and other human activities are undertaken. It is also the source of materials needed for these activities. Changes in land use have occurred at all times in the past, present, and are likely to continue in the future (Lambin, 2003; SC, 1996). Land-use/Landcover and its impacts on terrestrial ecosystems, including forestry, agriculture and biodiversity have been identified as high priority issues at global, national, and regional levels $(\underline{\mathrm{Fu}, 2000})$.

According to (Ramachandra 2012), land-use/land-cover (LU/LC) changes caused by natural and human processes have played a major role in global as well as regional scale patterns of the climate and other aspect of the earth. LU/LC dynamics are a result of complex interactions between several biophysical and socio-economic conditions, which may occur at various temporal and spatial scales (Reid, 2000). This kind of information is required in many aspects of land use planning and policy development, as a prerequisite for monitoring, modeling and environmental change and as a basis for land use statistics at all levels.

The massive LU/LC changes are a result of the need of land for settlement and agriculture in relation to the increasing human population, in fact that, challenging the objectives of the land management. Land-use should correspond to land capacity and it should respect the overall climatic condition and the environment (FAO/UNEP, 1999). Human population is increasing and causes transformation of the natural setting/environment into human landscapes. Therefore, it is critical to study to have detailed information, spatial and temporal LU/LC dynamics and the rate of changes. The main environmental problems in both rural and urban areas are due to conversion of vegetated surfaces into a settlement, bare land and agricultural land. Landuse/Land-cover dynamic is one of the main variables measured using Remote Sensing technology with different sensors such as, Landsat-5 TM, Landsat-7 ETM+ and Landsat-8 TIRS (Gebrekidan, 2016). A land cover change further disturbs the biogeochemical cycling that induces global warming, erosion of soil and land-use patterns.

Population growth is commonly blamed for widespread land-use change and environmental degradation (Cleaver, 1994). Due to the increase of population, industrialization and other natural and human activities (overgrazing, deforestation, unplanned land-use for settlement and other activities), its land use/land-cover patterns are changing. This indicate that change in LU/LC resulted in negative impacts on livelihood of farmers 
activities and leads environmental problems, thereby, challenging land management system and tenure security

Land management is a system of planning and management methods and techniques that aims to integrate ecological with social, economic and legal principles in the management of land for urban and rural development purposes to meet changing human needs, while simultaneously ensuring the long-term productive potential of natural resources and the maintenance of their environmental and cultural functions. However, changes in the land use land cover could have a quantitatively large impact on land management as well as rural productivity. This study, therefore, analysis land use/land cover change and its effects on land management in Adama Zuria District, Oromia region using Remote Sensing and GIS, in addition, the underlying causes were also identified using a household questionnaire. Regarding similar works on land use/land cover dynamics and its effect on land management in the study area (Adama Zuria District); there is one work, on modeling site suitability for wind farm using Remote Sensing and GIS technology: the case of Adama Woreda by (Belay, 2009). LU/LCC was analyzed; however, this study did not address its cause and consequences on land management. Therefore, the researcher intended to conduct the study on the impacts of land use/land cover change on land management. This research problem was identified by the researcher practical concern in the area to provide information on the change of LU/LC and causes and consequences of the changes.

Remote Sensing (RS) and Geographic Information System (GIS) provide the best capability to achieve spatially distributed information over wide area coverage and multi-temporal data to give sufficient information to anticipate the problems of LU/LC dynamics. Spatial data can help policy makers to decide recommendations for LU/LC dynamics to reduce the damage. The spatial and temporal information are needed for planning in overcoming the effects of LU/LC change. Sufficient data and information to anticipate various situations caused by changes in LU/LC are critical.

Adama Zuria District is characterized by diverse vegetation, climate and topographic pattern and different land use/land cover. Land use land cover of the study area was changed from time to time in the previous years .to this point, the Study proposed in this area.

\section{MATERIALS AND METHODS}

\subsection{Description of the Study area}

Adama Zuria Woreda is located in the Oromia regional state, Southeast of Addis Ababa, Ethiopia. It is about 100 $\mathrm{km}$ from Addis Ababa. The geographic location of the study area is between $8^{\circ} 14^{\prime} 0^{\prime \prime}-8^{\circ} 42^{\prime} 0^{\prime \prime} \mathrm{N}$ Latitude and $39^{\circ} 6^{\prime} 0^{\prime \prime}-39^{\circ} 27^{\prime} 0^{\prime \prime}$ E Longitude (Figure 1). The administrative center of the Woreda is Adama, covering a total area of $906.60 \mathrm{~km}^{2}$. The Altitude of the area range from $1415 \mathrm{~m}$ to $2505 \mathrm{~m}$ above sea level (Figure 1, (b)) and located within the Great Ethiopian Rift Valley. There are five neighboring areas of the Woreda. These are, Arsi Zone on the south, Koka Reservoir which separates it from Dugda Bora in the Southwest, Lome on the West, Amhara Region on the North and Boset on the East. The Awash River, defines the worked boundaries on the east and south. Other towns in this area include: Awash Melkasa, Shewa Alemtena, Sire Robi, Sodere and Wenji Gefersa.

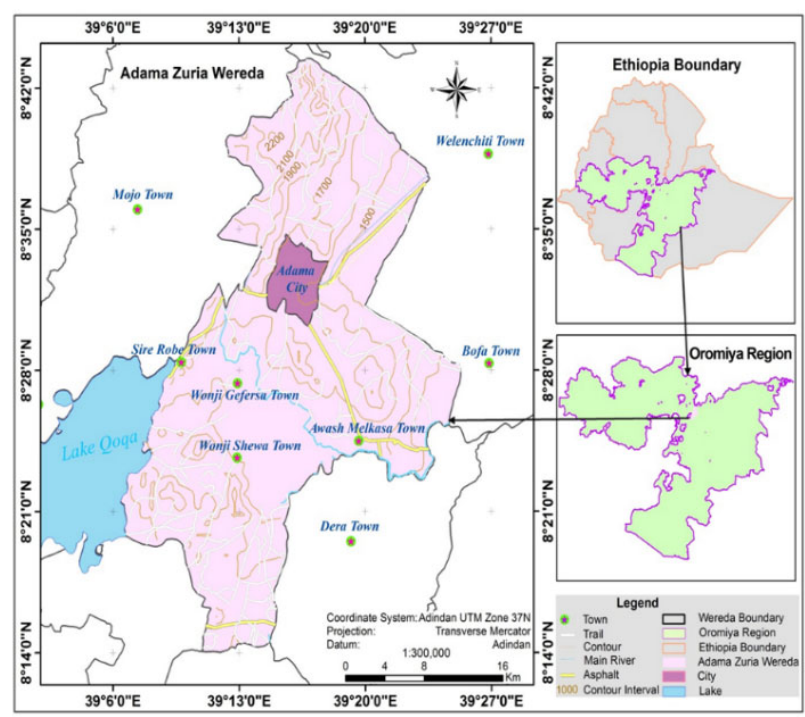

Figure 1. Location map of the study area

\subsection{Topography}

The Adama Zuria District has a wide-ranging flat area. However, in its northwest part, there is relatively rugged topography. The altitude of this Woreda ranges from 1415 to 2505 meters above sea level (Figure. 2, (a)). The 
slope of the Adama Zuria Woreda depicts that, $61.63 \%$ of the area is between 0 and $3^{\circ}, 25.55 \%$ of the area is between 3 and $6^{\circ}, 7 \%$ of the area between 6 and $11^{\circ}, 4 \%$ of the area is between $11-17^{\circ}, 1.1 \%$ is between 17 $26^{\circ}$ and $0.72 \%$ of the area is more than $26^{\circ}$ of slopes. Slope of the area with greater than $26^{\circ}$ is located in the north, northwest, southwest ridge part of the area.

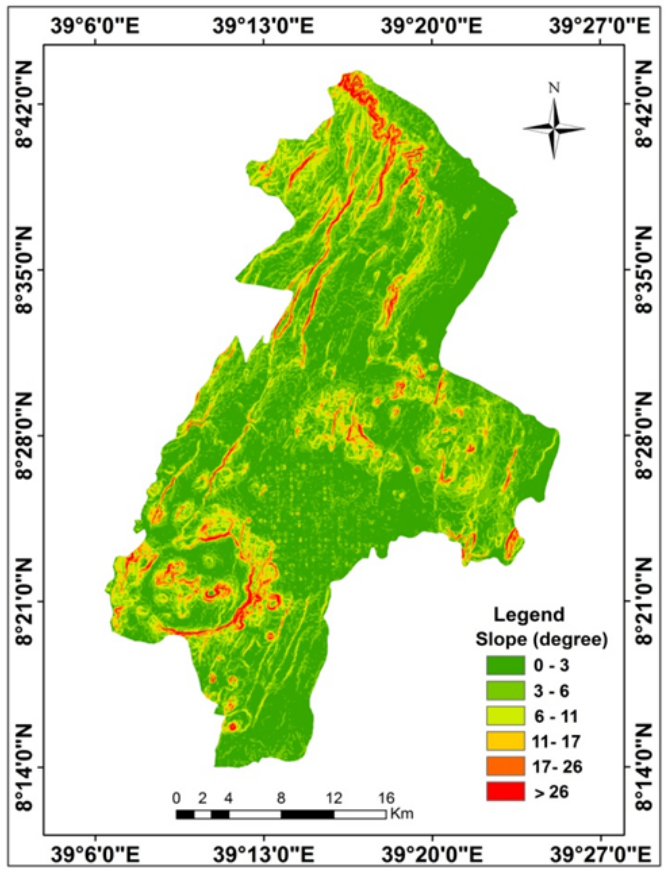

a)

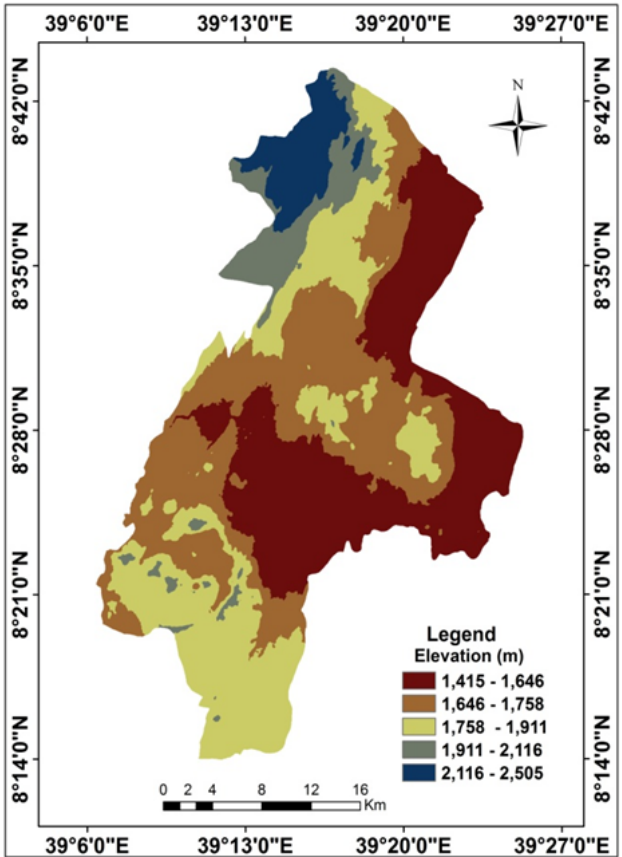

b)

Figure 2 (a), Slope and (b), Elevation map of the Study area

\subsection{Vegetation}

The vegetation distribution of the area is mainly dependent on the climate condition of the area. The climatic condition of the study area is characterized as tropical. On these types of climate, vegetation is scarce and typical examples are Shrub, Acacia and Scattered Trees of Eucalyptus. Eucalyptus trees, which is grown by local communities in a soil conservation program that is applied in the Main Ethiopian Rift Valley (MERV) to protect soil from erosion. The local people cultivate some types of crops cultivated in the area are Teff, Wheat, Barley, Maize and Sorghum. The harvesting season is between October and December at which the rain is very low.

\subsection{Population}

Based on the (CSA 2014), projected data (estimated population) census conducted by the Central Statistical Agency of Ethiopia (CSA), Adama Zuria District including Adama town has a total population of 475,385, of whom, 237,541 (49.97\%) were female and 237,844 (50.03\%) are male (Figure 3.).

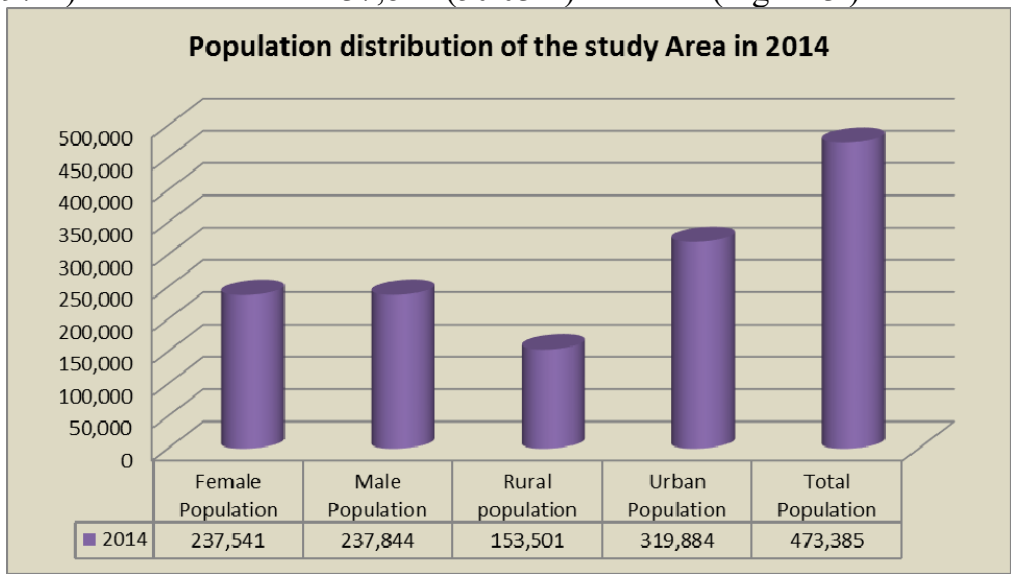

Figure 3. Population of the study area (CSA, 2014).

\subsection{Climate}

The climatic variables of the study area are highly governed by the topography of the area (mainly altitude). 


\subsubsection{Rainfall}

Adama Zuria meteorological station (Modjo, koka Dam, Sodare, Adama and Welenciti staton) from 1989-2017 reveals that the average rainfall recorded between 1989 and 1999 was $709.9 \mathrm{~mm}$, while 1999 and 2010 was $833.24 \mathrm{~mm}$ and for the years between 2010 and 2017 were 745 . Figure 4. below shows the distribution of annual rainfall.

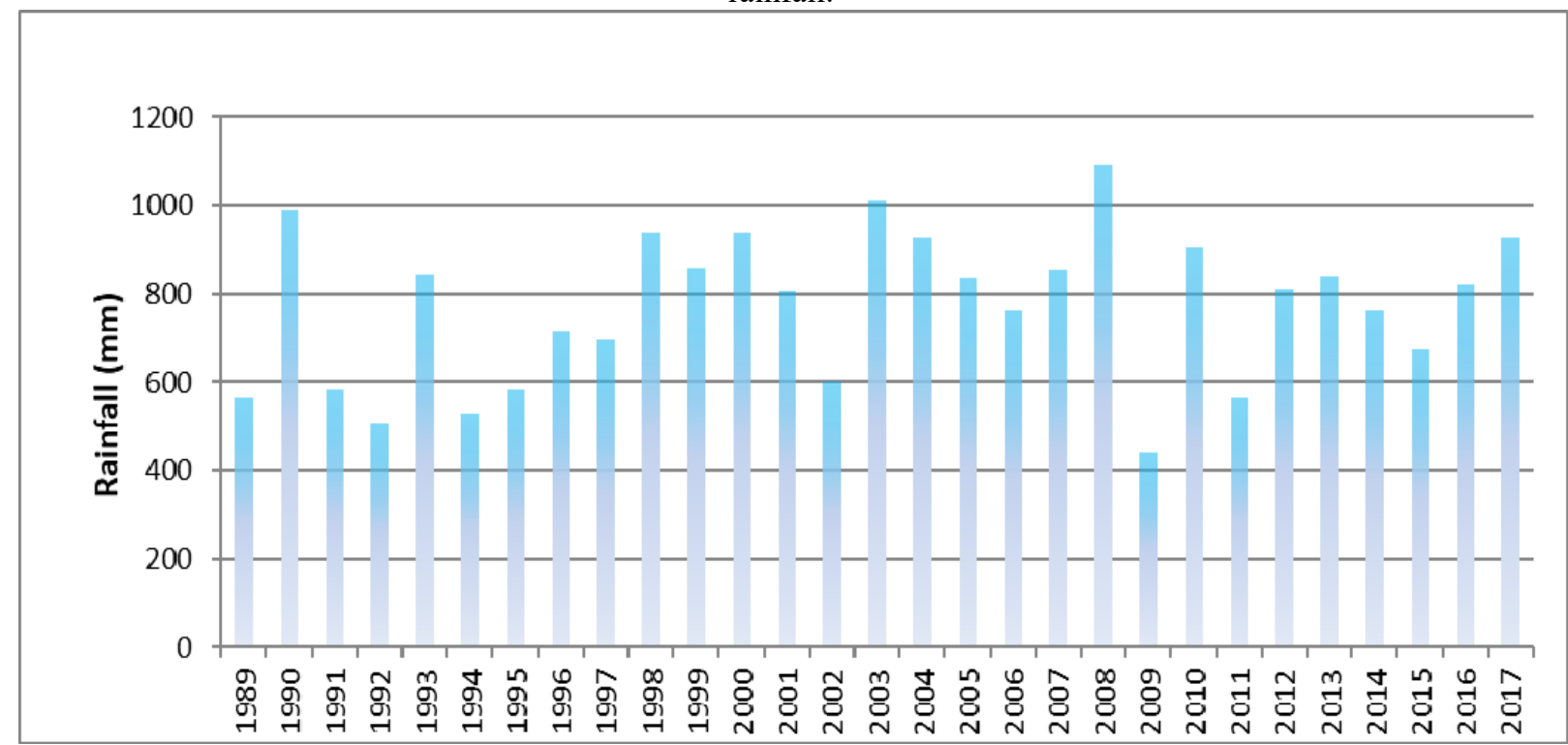

Figure 4. The distribution of annual rainfall of the study area (National Metrology Agency from 1989-2017) 2.5.2 Temperature

The mean annual temperature of the Adama Zuria Woreda is 27.8. It can be classified as semi humid to semiarid climate, which characterizes the altitude range between 1415 to $2505 \mathrm{~m}$ above mean sea level. In the study area, the hottest month with maximum mean temperature of $30.7^{\circ} \mathrm{C}$ was May. The below (Figure 5) present the mean annual temperature of the study area.

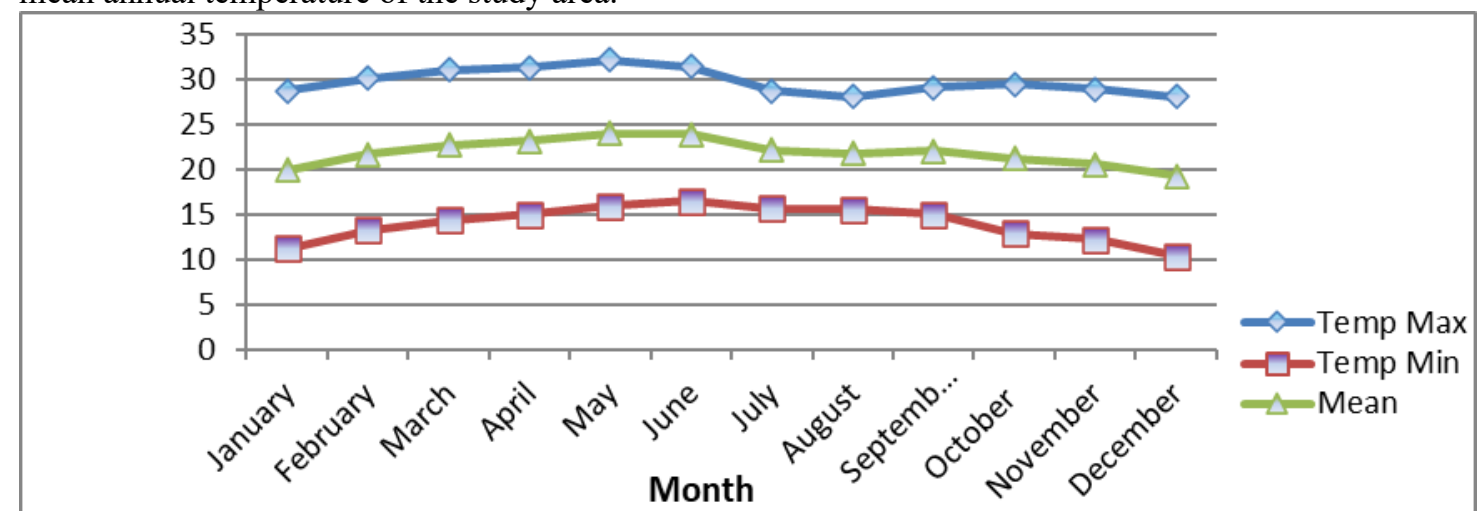

Figure 5. Max, Min and Mean Temperature of the study area

\subsection{Materials}

The data used for assessing LU/LCC in the study area is a time series of Landsat (TM, ETM+ and OLI) cloud free images of Landsat image (with path/row (168/054) were downloaded from USGS Global Visualization Viewer Website.

The softwares used in this study were chosen based on their capability to work on the existing problems in achieving the intended objectives. Therefore, the software packages used in this study were ERDAS Imagine 2014, ArcGIS 10.3, SPSS Version 21 and Microsoft excel 2013.

\subsection{Methodology}

2.7.1 Sampling design for household surveys

In this study, purposive sampling is employed due to the fact that, it is advantageous to access particular subset of people. The Adama Zuria Woreda has 37 kebeles. However, for the purpose of this study, due to the limited budget and time, three kebeles namely; Aroge Adama, Boku Kurabo and Wenji Shewa kebeles were selected purposively, expecting that all kebeles in Adama zuria have the same experience about the problem that the 
study describes. According to Woreda's record, a total number of the heads of households for sample kebeles is 382.

2.7.2 Research approach and sampling frame

The sampling frame for this study is the head of the households in selected three kebeles. Based on the Adama Zuria Woreda Land Administration records, the number of the head of the household in the three selected kebeles (the total households for the specified kebeles are Three Hundred Eighty the total households for the specified kebeles are Three Hundred Eighty-Two households (382). The sampling frame for this study is therefore, 382 households. Two households (382). The sampling frame for this study is therefore, 382 households Aroge Adama, Boku Kurabo and Wenji Shewa kebeles) are 170, 103 and 109 respectively. The total households for the specified kebeles are Three Hundred Eighty-Two households (382). The sampling frame for this study is therefore, 382 households.

\section{Sample size and its determination}

$\mathrm{n}=\mathrm{N} / 1+\mathrm{N}(\mathrm{e} 2)$

$\mathrm{n}=382 / 1+382(0.05) 2$

$\mathrm{n}=382 / 1+382(0.0025)$

$\mathrm{n}=382 / 1+0.955$

$\mathrm{n}=382 / 1.955$

$\mathrm{n}=195.39 \sim 195$

Whereas:

$\mathrm{N}=$ Number of population

$\mathrm{n}=$ Sample size

$\mathrm{e}=$ margin of error $(0.05)$

Aroge Adama: N1 = n $(\mathrm{N} 1 / \mathrm{N}) ; 195(170 / 382)=87$

Boku Kurabo: N2 = n (N2/N); 195(103/382) $=52$

Wenji Shewa: N3 = n (N3/N); 195(109/382) $=56$

$\mathrm{N} 1=\mathrm{n}(\mathrm{N} 1 / \mathrm{N})$; Where $\mathrm{N} 1=$ size of the strata, $\mathrm{N}=$ total population and $\mathrm{n}=$ total sample size to be selected.

Table 1. Population and sample taken from selected Kebeles.

\begin{tabular}{clcc}
\hline S. $\mathbf{N}$ & Selected Kebeles & Population & Sample size \\
\hline 1 & Aroge Adama & 170 & 87 \\
2 & Boku Kurabo & 103 & 52 \\
3 & Wenji Shewa & 109 & 56 \\
& Total & $\mathbf{3 8 2}$ & $\mathbf{1 9 5}$ \\
\hline
\end{tabular}

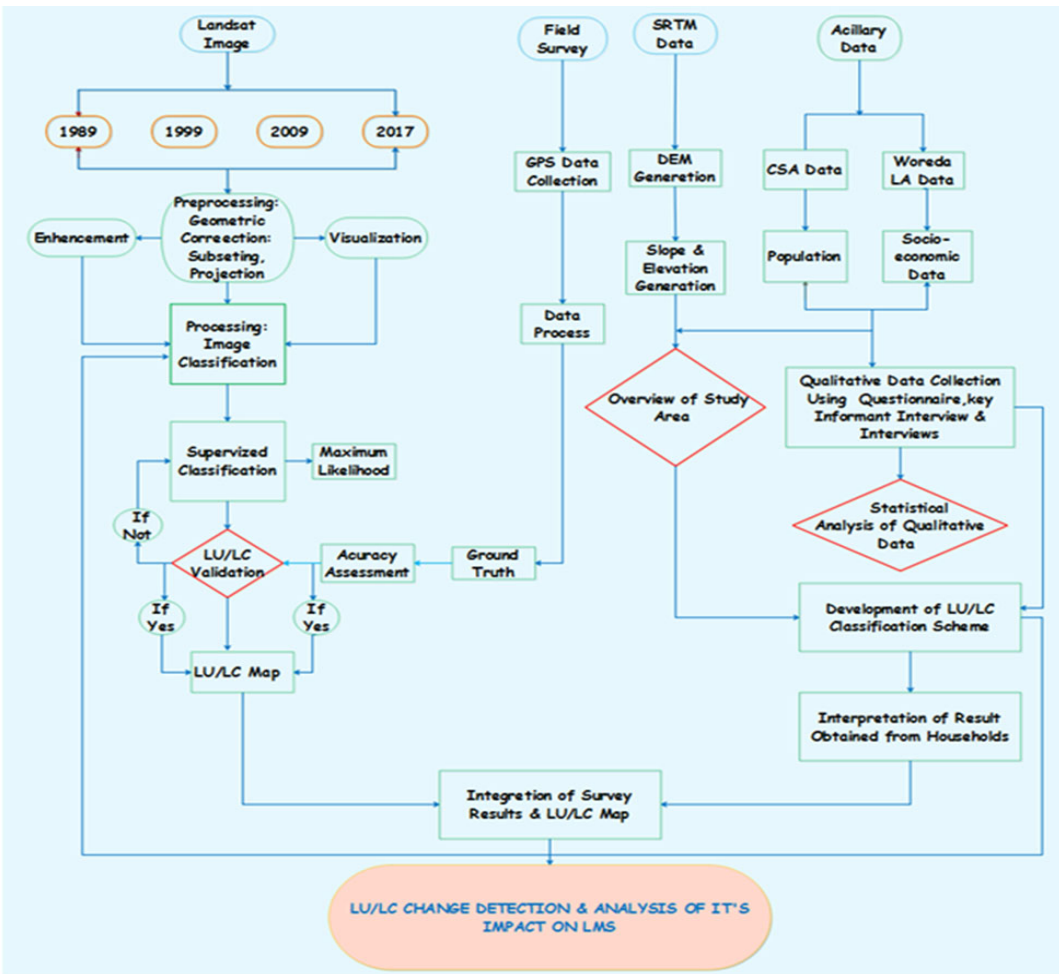

Figure 6. The overall workflow of the research 


\section{RESULTS AND DISCUSSION}

\subsection{Land Use and Land Cover Dynamics in Adama Zuria Woreda}

The information obtained from key informant, interpretation of remotely sensed imagery and field observation are the main points to classify the LU/LC classes in the study area. Consequently, the major LU/LC types identified includes: settlements (urban and rural), farmland, shrub lands, plantations, bare land and water body. The temporal analysis of land use/land cover maps between 1989 and 2017 presented in Table 2 and Figure 7 reveal that, the dynamics of the land use transformation, by identifying the amount of the land changing from one land cover type to another. Accordingly, in the 1989, farmland and shrub land were the dominant LU/LC type in the area. Out of the total $906.60 \mathrm{~km}^{2}, 548.02 \mathrm{~km}^{2}(60.44 \%)$ and $193.11 \mathrm{~km}^{2}(21.30 \%)$ area were covered by farmland and shrub land respectively. While the water body covers the smallest portion of the area, which is $2.58 \mathrm{~km}^{2}(0.28 \%)$. By 1999 , land brought to farmland and settlements increased by $68.97 \%$ and $2.98 \%$, respectively compared to 1989 . The increases in farmland and settlement lands were, however, paralleled by rapid declines in land area under the shrub land and bare land.

The pattern of LU/LC distribution in 2009 also followed a similar trend with that of 1999 . Hence, as can be seen from Table 2. farm land is yet again the main land use class, covering $626.23 \mathrm{~km}^{2}$ or $69.07 \%$ of the total area followed by shrub land, which represent $102.76 \mathrm{~km}^{2}$ or $11.33 \%$ of the total area. Similarly, settlement and plantation land showed a big incremental change from the previous decades $\left(27.1 \mathrm{~km}^{2}\right.$ to $34.72 \mathrm{~km}^{2}$ and 74.30 $\mathrm{km}^{2}$ to $76.80 \mathrm{~km}^{2}$ ) respectively from 1999 to 2009 .

The results from the time period of 2017 portray the main LU/LC classes were also farmland and shrub land, which together constituted $79.88 \%$ of the total area coverage. Farmland accounted for $68.47 \%$ ) and shrub land accounted for $(11.41 \%)$. The remaining percentage $(20.12 \%)$ has covered by bare land, plantation, settlement and water body. However, the extent of farmland 2017 has decreased by $0.6 \%$ compared to 2009 . Overall, in the study period, settlement, farmland and plantation has been increased, whereas bare land and shrub land has been shrinking, while water body fluctuated through time. Table 2 and Figure 7 illustrate the LU/LC classes, as well as area coverage and map of land use land cover change in the year between 1989- 2017.

Table 2. Summaries of LU/LC classes and area coverage of 1989, 1999, 2009 and 2017

\begin{tabular}{|l|l|l|l|l|l|l|l|l|l|}
\hline No & LU/LC Classes & \multicolumn{2}{|c|}{$\mathbf{1 9 8 9}$} & \multicolumn{2}{|c|}{$\mathbf{1 9 9 9}$} & \multicolumn{2}{|c|}{$\mathbf{2 0 0 9}$} & \multicolumn{2}{|c|}{$\mathbf{2 0 1 7}$} \\
\hline & & $\begin{array}{l}\text { Area } \\
\left(\mathrm{km}^{2}\right)\end{array}$ & Area $(\%)$ & $\begin{array}{l}\text { Area } \\
\left(\mathrm{km}^{2}\right)\end{array}$ & Area $(\%)$ & $\begin{array}{l}\text { Area } \\
\left(\mathrm{km}^{2}\right)\end{array}$ & Area $(\%)$ & $\begin{array}{l}\text { Area } \\
\left(\mathrm{km}^{2}\right)\end{array}$ & Area $(\%)$ \\
\hline $\mathbf{1}$ & Settlement & 7.55 & 0.83 & 27.1 & 2.98 & 34.72 & 3.82 & 56.50 & 6.23 \\
\hline $\mathbf{2}$ & Farmland & 548.02 & 60.44 & 625.37 & 68.97 & 626.23 & 69.07 & 620.80 & 68.47 \\
\hline $\mathbf{3}$ & Shrub Land & 193.11 & 21.30 & 106.30 & 11.72 & 102.76 & 11.33 & 103.46 & 11.41 \\
\hline $\mathbf{4}$ & Plantation & 71.24 & 7.85 & 74.30 & 8.19 & 76.80 & 8.47 & 81.40 & 8.97 \\
\hline $\mathbf{5}$ & Bare land & 84.1 & 9.27 & 70.52 & 7.77 & 63.08 & 6.95 & 41.46 & 4.57 \\
\hline $\mathbf{6}$ & Water Body & 2.58 & 0.28 & 3.11 & 0.34 & 3.01 & 0.33 & 2.98 & 0.32 \\
\hline & Total & $\mathbf{9 0 6 . 6 0}$ & $\mathbf{1 0 0}$ & $\mathbf{9 0 6 . 6 0}$ & $\mathbf{1 0 0}$ & $\mathbf{9 0 6 . 6 0}$ & $\mathbf{1 0 0}$ & $\mathbf{9 0 6 . 6 0}$ & $\mathbf{1 0 0}$ \\
\hline
\end{tabular}



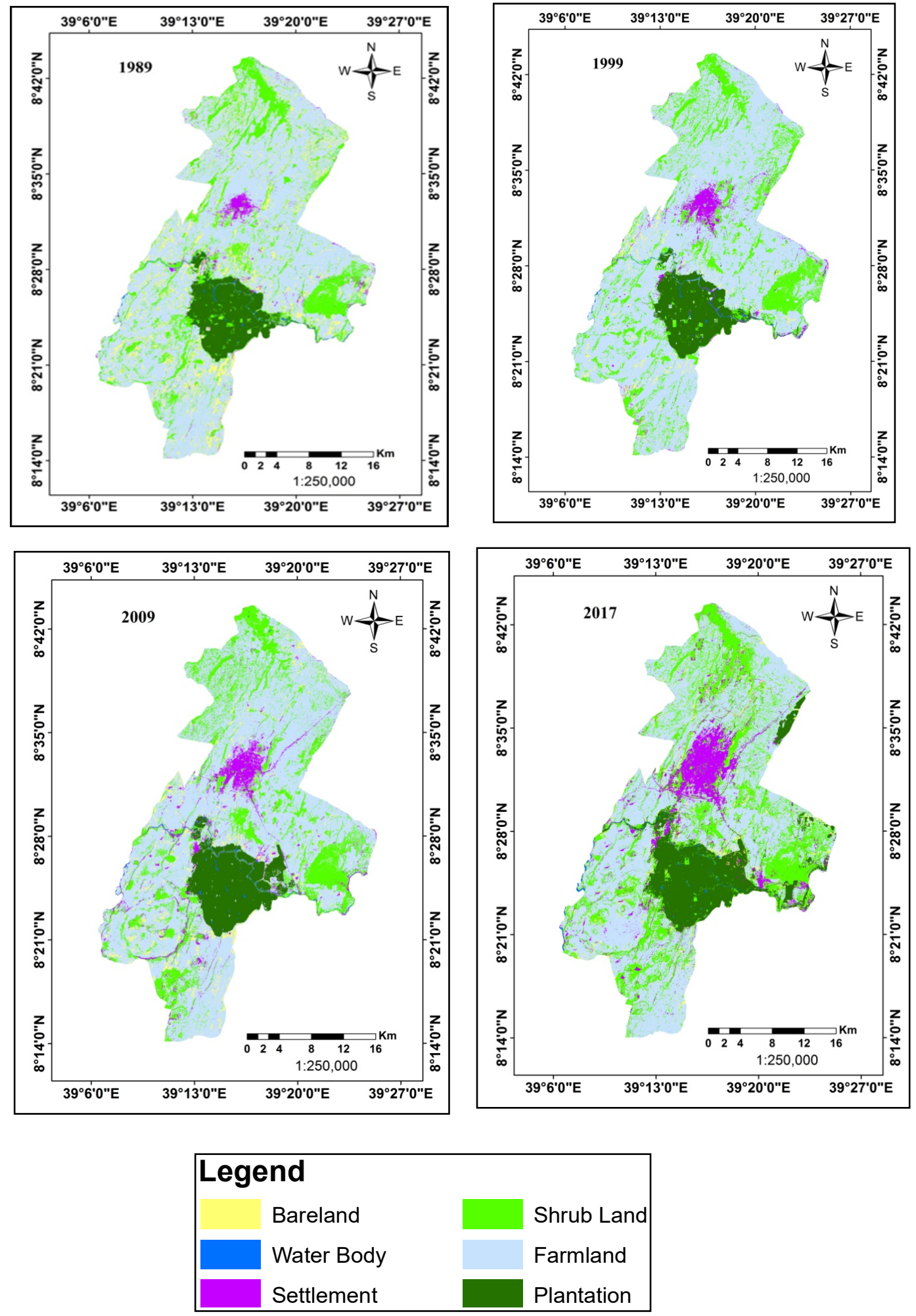

Figure 7. Land-use/land-cover change maps of the study area from 1989 -2017

\subsection{The extent of land use and land cover in the study area}

The land use/land cover analysis of the study area based on the satellite image confirmed that, LU/LC patterns in the District have shown a significant change in between 1989 and 2017 years. Among the six major LU/LC classes, farmland and shrub land covered more than $80 \%$ of the area in all the study years. A Settlement has been increased from 1989 to 2017. It has increased from $7.55 \mathrm{~km}^{2}$ in 1989 to $56.50 \mathrm{~km}^{2}$ in 2017 (Table 3). The plantation also increased from 1989 to 2017 . It increased from $71.24 \mathrm{~km} \%$ by 1989 to $74.30 \mathrm{Km}^{2}$ by 1999 and 
$76.80 \mathrm{Km}^{2}$ by 2009 and $81.40 \mathrm{Km}^{2}$ in 2017. Shrub land and water body showed fluctuations from 1989 to 2017. Shrub land was $193.11 \mathrm{Km}^{2}$ in 1989 , which was decreased to $106.30 \mathrm{Km}^{2}$ by 1999 , again decreased to 102.76 $\mathrm{Km}^{2}$ in 2009 and then increased to $103.46 \mathrm{Km}^{2}$ by 2017 . Water body also has changed from $0.28 \%$ in 1989 to $0.34 \%$ by 1999 and then decreased to $0.33 \%$ by 2009 , finally the trends of water body again decreased to $0.32 \%$ in 2017 . The area coverage of the farmland increased from $548.02 \mathrm{~km} 2$ by 1989 to $625.37 \mathrm{~km}^{2}$ by $1999,626.23$ $\mathrm{km}^{2}$ in 2009 and decreased to $620.80 \mathrm{~km}^{2}$ in 2017. Bare land showed a continuous decrement from 1989-2017. Overall, the net changes of LU/LC between $1989-2017$ presented in Table 3

Table 3 Land use land cover change and conversion rate between 1989 -2017

\begin{tabular}{|c|c|c|c|c|c|c|}
\hline No & LU/LC Classes & 1989 & 1999 & 2009 & 2017 & $\begin{array}{l}\text { Change rate between } \\
\text { 1989-2017 }\end{array}$ \\
\hline & & Area $\left(\mathrm{km}^{2}\right)$ & Area $\left(\mathrm{km}^{2}\right)$ & Area $\left(\mathrm{km}^{2}\right)$ & $\begin{array}{l}\text { Area } \\
\left(\mathrm{km}^{2}\right)\end{array}$ & Area $\left(\mathrm{km}^{2}\right)$ \\
\hline 1 & Settlement & 7.55 & 27.1 & 34.72 & 56.50 & +48.95 \\
\hline 2 & Farmland & 548.02 & 625.37 & 626.23 & 620.80 & +72.78 \\
\hline 3 & Shrub Land & 193.11 & 106.30 & 102.76 & 103.46 & -89.65 \\
\hline 4 & Plantation & 71.24 & 74.30 & 76.80 & 81.40 & +10.16 \\
\hline 5 & Bare land & 84.1 & 70.52 & 63.08 & 41.46 & -42.64 \\
\hline \multirow[t]{2}{*}{6} & Water Body & 2.58 & 3.11 & 3.01 & 2.98 & +0.4 \\
\hline & Total & 906.60 & 906.60 & 906.60 & 906.60 & \\
\hline
\end{tabular}

The above Table illustrates the net change observed in land use/land cover of the study area at a specified time. Accordingly, shrub land and bare land have been decreased by $89.65 \mathrm{~km} 2$ and $42.64 \mathrm{~km}^{2}$ respectively. However, settlement, farmland and plantation increased by $48.95 \mathrm{~km}^{2}, 72.78 \mathrm{~km}^{2}$ and $10.16 \mathrm{~km}^{2}$ respectively (Table 3). As revealed from household surveys, most of the respondents argued that population pressure imposed on resource has a serious impact on the changes of those all land use land cover in the study area.

\subsection{Result of socio-economic survey}

The land use and land cover changes were triggered by different causative factors which may lead to an irreversible environmental problems and natural resource degradation. In one way or another, the change in land use and land cover is the reflection of the socio-economic condition of the surrounding community. The human activities and natural processes are the responsible factors for LULC change in the study area. Land use/ land cover change is always caused by multiple interacting factors. The mix of driving forces of land use change varies in time and space according to specific human environmental conditions. Accordingly, the underlying causes operate at the local level were identified from the household survey conducted in the relatively high change Kebeles. There are conditions which were identified as important points before discussing the results of the underlying causes of land use/land cover change to link the result with the underlying facts. The Points that have been seen in this topic are: demographic profile of the respondents, land use land cover change, Causes for the land use/land cover change and the impacts of land use/land cover change on the land management in the study area. Table 4 shows respondent rate involved in the study.

\subsection{Response rate}

Table 4 Showing response rate

\begin{tabular}{|c|c|c|c|c|c|}
\hline \multirow{3}{*}{ S. $\mathbf{N}$} & \multirow{3}{*}{ Kebele } & \multicolumn{4}{|c|}{ Number of Participants } \\
\hline & & \multicolumn{2}{|c|}{ In sample size } & \multicolumn{2}{|c|}{ Returned questionnaire } \\
\hline & & Frequency & Percentage & Frequency & Percentage \\
\hline 1 & Aroge Adama & 87 & $44 \%$ & 87 & $44 \%$ \\
\hline 3 & Boku Kurabo & 52 & $27 \%$ & 52 & $27 \%$ \\
\hline 4 & Wenji Shewa & 56 & $29 \%$ & 56 & $29 \%$ \\
\hline & Total & 195 & $100 \%$ & 195 & $100 \%$ \\
\hline
\end{tabular}

Among one hundred ninety-five participants of the study, all respondents that means $195(100 \%)$ have returned the questionnaire. Therefore, the analysis has been presented based on participants who have been returned the questionnaire.

\subsection{Demographic profiles of respondents}

This section describes demographic characteristics of the respondents which include: sex composition of the respondents, age category of the respondents, respondents' educational level, marital status of household, occupation status of the respondents, and family size of the respondents. 
3.5.1 Sex composition and age category of the respondents

Table 5 Distribution of respondents by sex and age category

\begin{tabular}{cccc}
\hline & & \multicolumn{1}{c}{ Descriptive Statistics } & Percentage \\
\hline $\mathbf{S . ~} \mathbf{N}$ & Sex & Frequency & $29.7 \%$ \\
$\mathbf{1}$ & Female & 58 & $70.3 \%$ \\
& Male & 137 & $\mathbf{1 0 0 . 0} \%$ \\
$\mathbf{2}$ & Total & $\mathbf{1 9 5}$ & $82.6 \%$ \\
& & Age category of the respondents & $13.8 \%$ \\
& $18-30$ Years & 161 & $3.1 \%$ \\
& $31-40$ Years & 27 & $.5 \%$ \\
& $41-50$ Years & 6 & $\mathbf{1 0 0 . 0}$ \\
\hline
\end{tabular}

Source: Field Survey 2018

The above table number 1 depicts the sex composition of respondents. $29.7 \%$ respondents were females while $70.3 \%$ of them were males. According to the finding indicated in the above table item 2, respondents' ages were range between 18 to above 50 years old. Respondents who were between the ages of 18-30 years old comprise $82.6 \%$ of the surveyed population. About $13.8 \%$ of the participants were within the age range of $31-40$ years of age. While $3.1 \%$ and $0.5 \%$ of the respondents were within the age range of $41-50$ and greater than 50 respectively. In relation to their age, the majority of respondents were within the age of 18-30 years of age at the time of interview. This indicates that the majority of respondents are found to be in the range of productive age. 3.5.2 Marital status

Analysis of the data indicated that 66.2 percent of the respondents were currently married; while single, divorced and widowed constitute 21.0, 9.2 and 3.6 percent respectively. Table 6 present data on the marital status of the respondents.

Table 6 Marital status of respondents

\begin{tabular}{cccc}
\hline S. $\mathbf{N}$ & Response & Frequency & Percentage \\
\hline 1 & Single & 41 & $21.0 \%$ \\
2 & Married & 129 & $66.2 \%$ \\
3 & Divorced & 18 & $9.2 \%$ \\
4 & Widowed & 7 & $3.6 \%$ \\
& Total & $\mathbf{1 9 5}$ & $\mathbf{1 0 0 . 0} \%$ \\
\hline
\end{tabular}

3.5.3 Educational background of respondents

Source: Field Survey 2018

\section{Educational Background of Respondents}

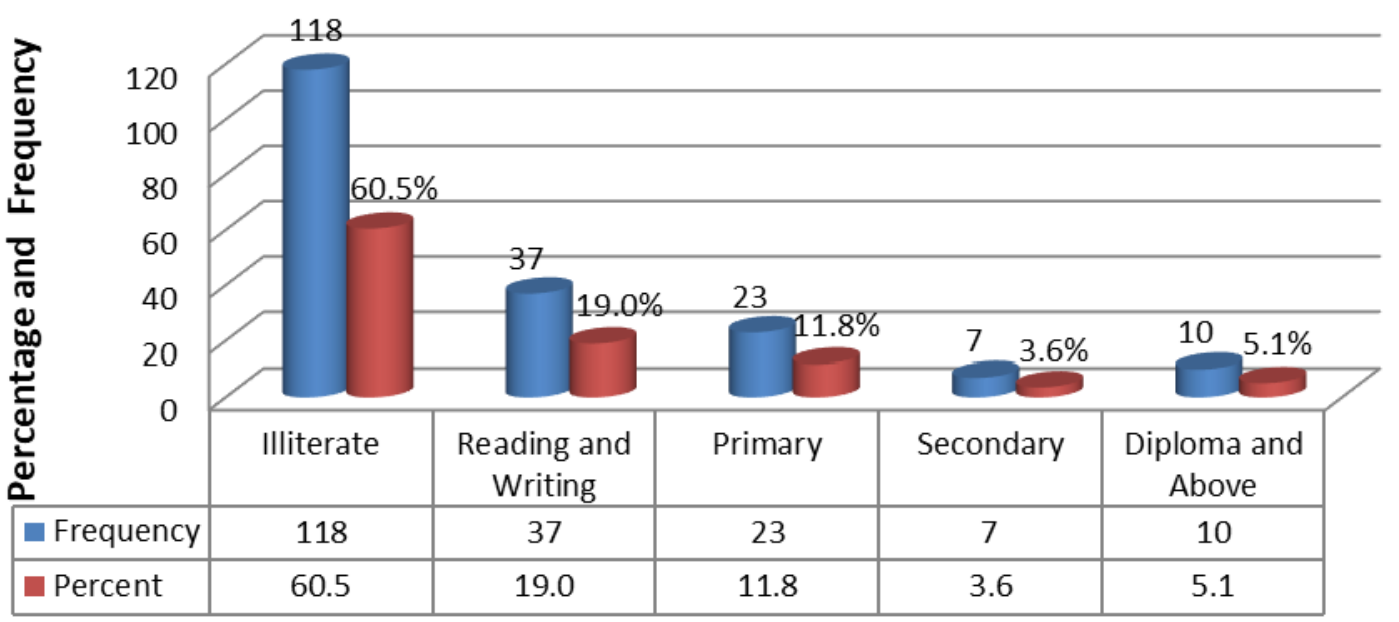

Figure 8. Distribution of respondents by the level of education

The survey revealed the educational characteristics of respondents from illiterate to higher education level. The above Figure manipulates the distribution of the respondents by level of education. Based on the above Figure, 60.5 percent of the respondents were totally illiterate or cannot read and write, $19.0 \%$ respondents' educational background was reading and writing only. About 11.8 and 3.6 percent of the respondents were attending primary and secondary school respectively. The remaining $5.1 \%$ of them were attending higher 
education level, i.e., diploma and above during the time of interview. As the Figure shows, the majority of the respondents' educational level found to be an illiterate. This indicates that they mainly depend on agricultural activities. This situation can lead expansion of the farmland, as a consequence, causes for LU/LCC.

3.5.4 Occupation characteristic of respondents

Occupational characteristic of the respondents in showed in Figure 9.

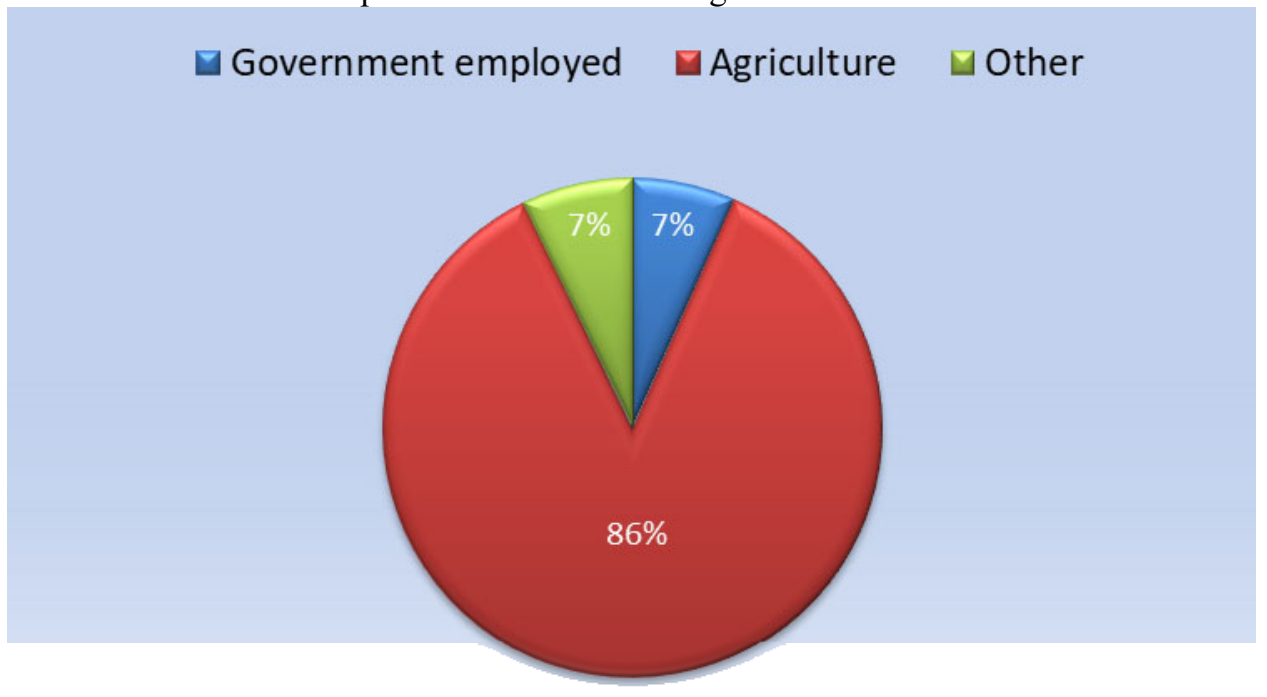

Figure 9. Reveals occupation characteristic of respondents

An analysis of the Figure above reveals the occupational status of respondents. Accordingly, $86 \%$ of the respondents responded that they were engaged in agriculture, $7 \%$ of the participants of the study agreed that they engaged in government employee (Figure 9). While the remaining 7\% were engaged in other activities (selfemployed) such as: wood work, metal work and shopkeepers at the time of the interview. Therefore, the occupational activities in the study area were a factor in land use/ land cover change. For instance, $86 \%$ of the respondents were farmers; this indicates a high number of farmers in the area have been accelerating change in land use land cover.

3.5.5 Family size of the respondents

Table 7 Showing the family size of the respondents

\begin{tabular}{cccc}
\hline S.N & Response & Frequency & Percentage \\
\hline 1 & $1-4$ & 99 & $50.8 \%$ \\
2 & $5-7$ & 55 & $28.2 \%$ \\
3 & $8-10$ & 36 & $18.5 \%$ \\
4 & More than ten & 5 & $2.6 \%$ \\
& Total & $\mathbf{1 9 5}$ & $\mathbf{1 0 0 . 0 \%}$ \\
\hline
\end{tabular}

\section{Source: Field Survey 2018}

Based on the findings of the study, family size of respondents was specified. Accordingly, 50.8\% ( $\mathrm{n}=99)$ were within the family members of $1-4$ category, $28.2 \%(n=55)$ of the respondent's family member in a house within the range of 5-7 family members, while $18.5 \%(\mathrm{n}=36)$ and $2.6 \%(\mathrm{n}=5)$ of the respondent's family size were labeled in the range of 8-10 and greater than 10 respectively (Table 7). One can conclude from this that as the number of people/family size increased in a given place within scarce land resource, people enforced to change land use land cover to another type. Similarly, Aman Ahmad, who has been living in Boku Kurabo kebele during the interview on Thursday, April 23, 2018 at 3:20Am, state that, due to population pressure (high number of family size), land use /land cover in the study area changed from time to time, for instance, bare land and shrub land changed into farmland and settlement.

\subsubsection{Land acquisition}

Another question that the researcher raised during the data collection was 'what is your means of land acquisition?'; As indicated in the Figure 10, of the sample households, 59.5\% of landowners were through first distribution and $16.4 \%$ were by inheritance, while the remaining 9.2, 8.2 and 6.7 percent of the respondents were through the gift, share cropping and renting respectively. The figure shows that, after first distribution, the next coming generation has expected to be a landless due to scarcity of land resource. 


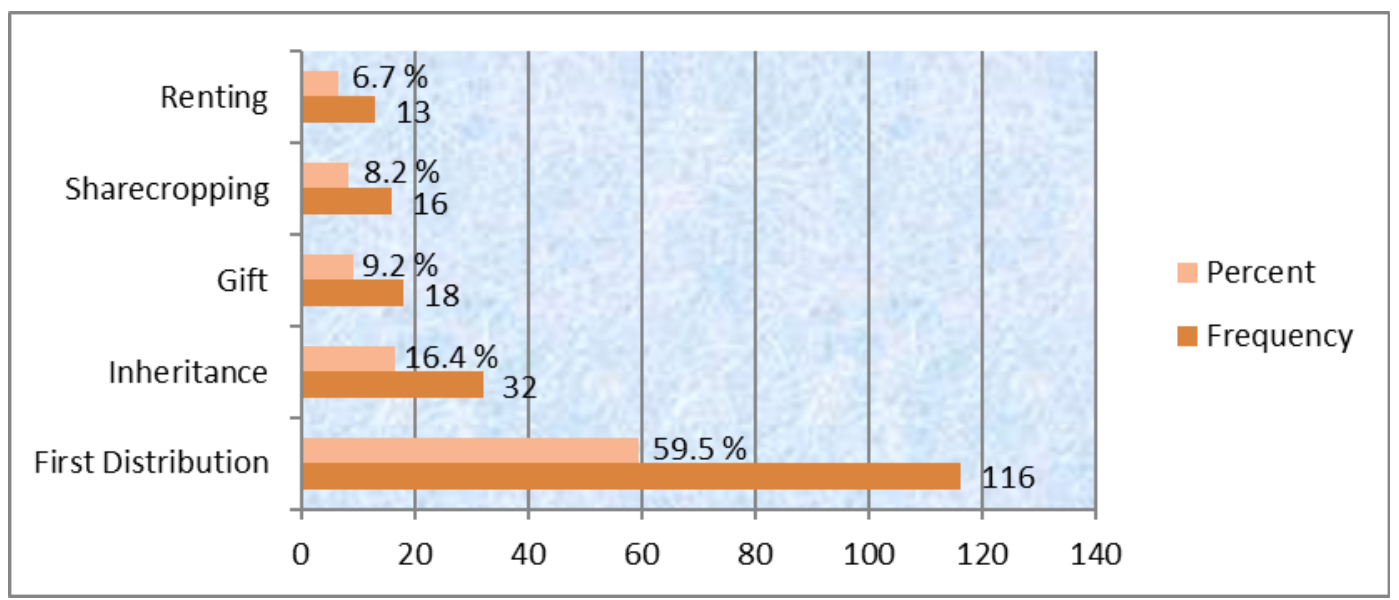

\subsubsection{Land Size}

Figure 10. Land acquisition systems of the respondents

The landholding of peasants in the study area varied from timad to hectare. 58.8 percent of the respondents reported that they own 1 timad $(0.25$ hectare $)$ to 2 hectare. While $37.9,6.7$, and 1.5 percent of the respondents own land from $2-4,4-6$ and more than six hectare respectively. The majority of respondents $(58.8 \%)$ has own from one timad to two hectare (Table 8).

Table 8 Showing percentage distribution of the respondents by land holding size

\begin{tabular}{cccc}
\hline S.N & Land size & Frequency & Percentage \\
\hline $\mathbf{1}$ & 1 timad - 2 Hectare & 105 & $58 . .8 \%$ \\
$\mathbf{2}$ & $2-4$ & 74 & $37.9 \%$ \\
$\mathbf{3}$ & $4-6$ & 13 & $6.7 \%$ \\
$\mathbf{4}$ & More than 6 & 3 & $1.5 \%$ \\
& Total & $\mathbf{1 9 5}$ & $\mathbf{1 0 0 . 0 \%}$ \\
\hline
\end{tabular}

Source: Field Survey 2018

\subsection{Respondents perception toward LU/LCC in the study area}

LULC change reflects both the biophysical conditions and the history of the socio-economic setting of a given area. Hence, a household survey was conducted to acquire data relating to the socio-economic and demographic conditions of households which would help to explain the changes observed in the LULC. Respondents were asked about change occurred on land use/land cover in their area, accordingly, 96.9 percent of the respondents replied that there is a land use land cover change, while $1 \%$ stated that there is no change as such and 2.1 percent replied uncertainly to respond. Similarly, information extracted from satellite image (Figure 10) confirms the change observed in the study area. See Figure 10 below.

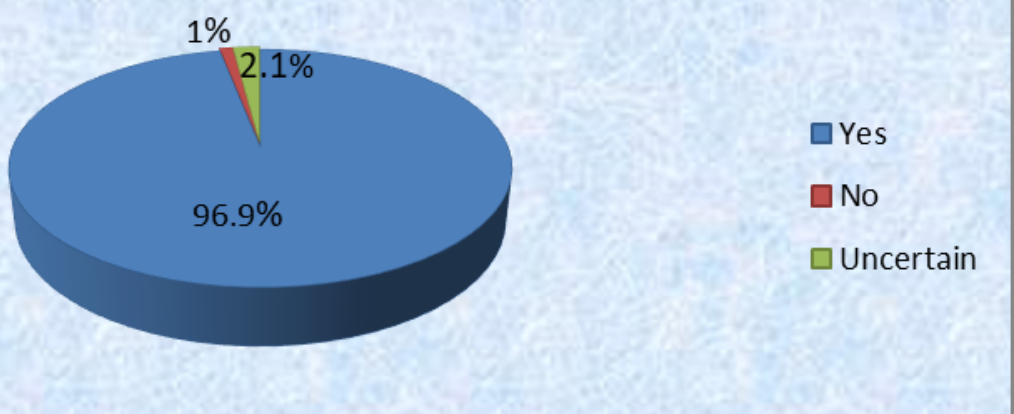

Figure 11. Showing the perception of respondents in LU/LCC

The respondents were also asked to point out the changes observed in LU/LC, based on the Table 9, Out of a total of 195 responses, $53.8 \%$ (or 105/195) of households reported that plantation is increased, 67.7\% (or $132 / 195$ ) of the respondents said deceased in bare land, $77.4 \%$ (or 151/195) of the respondent replied that shrub land decreased, 96.4\% (or 188/195)of the respondents said farmland increased, 99.5\%(or 194/195) of the respondents respond no change in the water body and $96.9 \%$ (or 189/195) of the respondents replied settlement in the study area was increased. Similarly, the results from satellite image classification/analysis of time series of four decades $(1989,1999,2009$ and 2017) illustrates that the trend of change in land use land cover is very high (i.e. increased in the settlement pattern, farmland and plantation cover, while shrub and bare land has decreased. Table 9 below is a frequency table and percentage of the results. 
Table 9 Showing the distribution of the respondents in the validation of LU/LC changes

\begin{tabular}{cccccccc}
\hline S.N & LU/LC Class & Increased & Percent & Decreased & Percent & No change & Percent \\
\hline $\mathbf{1}$ & Plantation & 105 & $53.8 \%$ & 38 & $19.5 \%$ & 52 & $26.7 \%$ \\
$\mathbf{2}$ & Bare land & 21 & $10.8 \%$ & 132 & $67.7 \%$ & 42 & $21.5 \%$ \\
$\mathbf{3}$ & Shrub land & 10 & $5.1 \%$ & 151 & $77.4 \%$ & 34 & $17.4 \%$ \\
$\mathbf{4}$ & Farmland & 188 & $96.4 \%$ & 4 & $2.1 \%$ & 3 & $1.5 \%$ \\
$\mathbf{5}$ & Water Body & - & - & 1 & $0.5 \%$ & 194 & $99.5 \%$ \\
$\mathbf{6}$ & Settlement & 189 & $96.9 \%$ & 2 & $1.0 \%$ & 4 & $2.1 \%$ \\
& Total & & $\mathbf{1 0 0}$ & $\mathbf{1 9 5}$ & $\mathbf{1 0 0}$ & $\mathbf{1 9 5}$ & $\mathbf{1 0 0}$ \\
\hline
\end{tabular}

\subsection{Land use/land cover change drivers}

The underlying causes of land use/land cover change explain how and why local land cover and ecosystem processes are modified. With this regard, respondents were asked the causes of land use land cover change, as of Table 10, 84.7 percent of the respondents agree that population increase is the cause for the change and $74.9 \%$ were confirm the expansion of settlement and town toward the farmland and other land use types causes for land use/land cover change. While $75.4 \%, 49.2 \%, 60.5 \%$ and $77.9 \%$ of the respondents were realized, lack of tenure security /certification, Environmental problems, expansion of the infrastructure and social services and lack of proper management of the land contributes land use/land cover change. Similarly, Houghton, (1994) state that changes in the land-use reflects the history and perhaps, the future of humankind. Such changes are influenced by a variety of factors related to human population growth, economic development, technology and environmental changes. Besides, at the time of the interview, Hiwot Tesfaye, land administration officer argued that, increase demand/population growth, deforestation, development of the infrastructure, transaction of the land, formal and informal settlement were the main cause for the land use land cover change. From the above analysis, it is clear that population growth is the major cause for both land scarcity and land use land cover change in the study area. Table 10 report the perception of respondents toward the cause of the LU/LC changes in the study area.

Table 10 The distribution of the respondents toward the cause for LU/LC change

\begin{tabular}{|c|c|c|c|c|c|c|c|}
\hline S.N & Cause for $L U / L C$ change & Agree & Percent & Disagree & Percent & Undecided & Percent \\
\hline 1 & $\begin{array}{l}\text { Population growth is the reason for } \\
\text { land use/land cover change }\end{array}$ & 164 & $84.7 \%$ & 24 & $12.3 \%$ & 7 & $3.6 \%$ \\
\hline 2 & $\begin{array}{l}\text { Expansion of settlement and town } \\
\text { toward the farmland causes for land } \\
\text { use/land cover change }\end{array}$ & 146 & $74.9 \%$ & 26 & $11.8 \%$ & 23 & $13.3 \%$ \\
\hline 3 & 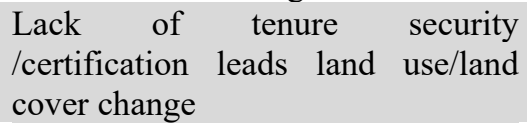 & 147 & $75.4 \%$ & 41 & $21.0 \%$ & 7 & $3.6 \%$ \\
\hline 4 & $\begin{array}{l}\text { Environmental problems is the } \\
\text { cause for land use/land cover } \\
\text { change }\end{array}$ & 96 & $49.2 \%$ & 83 & $42.6 \%$ & 16 & $8.2 \%$ \\
\hline 5 & $\begin{array}{l}\text { Expansion of the infrastructure and } \\
\text { social services causes land use/land } \\
\text { cover change }\end{array}$ & 118 & $60.5 \%$ & 4 & $2.1 \%$ & 73 & $37.4 \%$ \\
\hline 6 & $\begin{array}{l}\text { Lack of proper management of land } \\
\text { contributes land use/land cover } \\
\text { change }\end{array}$ & 152 & $77.9 \%$ & 35 & $17.9 \%$ & 8 & $4.1 \%$ \\
\hline
\end{tabular}

A focus group discussion was also employed to get insight about the underlying causes of land use /land cover change in the study area. Accordingly, the members of the focus group discussion underlined that generally there is a decrease in shrub land, while increase in the farm land and settlement. This discussion result also supports the LULC change analysis. The group also discusses the cause for the change and underlined that population growth is the major factor for the change, but there are some who argued that it is mismanagement and poor agricultural practices which were responsible for the change in the study area.

\subsection{The impacts of LU/LC change on the livelihood of the farmers activities}

Farmers in the study area are largely dependent on the agriculture. Crop production activities are the main livelihood strategies of households. The temporal decline in crop productivity has a key impact on household food insecurity. declination of crop productivity is arise from land degradation, limited use of organic fertilizers and little success from use of synthetic fertilizers, low crop diversity, decline in size of household level land holding and landlessness appear to be major challenges facing the crop production. The majority of problems 
listed above were due to land use and land cover change. Land degradation in the form of gully erosion is reported to be a problem in study areas, which brought significant area of cultivated land out of production. Unsustainable and improper land use and land cover changes are the major causes of land degradation.

The survey is conducted regarding with the productivity of the respondent farmland/own plots, leased plots and share cropping over the previous years to investigate the impacts of the land use land cover changes on the livelihood of the societies. As shown in Figure 4.8 below, $7.2 \%$ of the respondents were not decided whether their productivity increased or not. About $17.9 \%$ of the respondents agreed that their productivity was increased and 61.1 percent of the respondents confirmed that there was decreased in land productivity. While 10.3 percent reply no change. The researcher also asked the reason for the decline in the productivity.

Besides, according to Kafale Regasa, April 22, 2018 at 4:40 Am, at the time of the interview, lack of technology, lack of soil nutrition, intensive use of the land without crop rotation due to the scarcity of the land, change in the land use /land cover (from farmland to the settlement in the interior city) and land degradation in the study area were among the reason for the declination of the productivity in the study area. From the above explanatory attributes, it can be said that land use land cover change plays the important role in the declination of the productivity in the study area. See Figure 4.6.

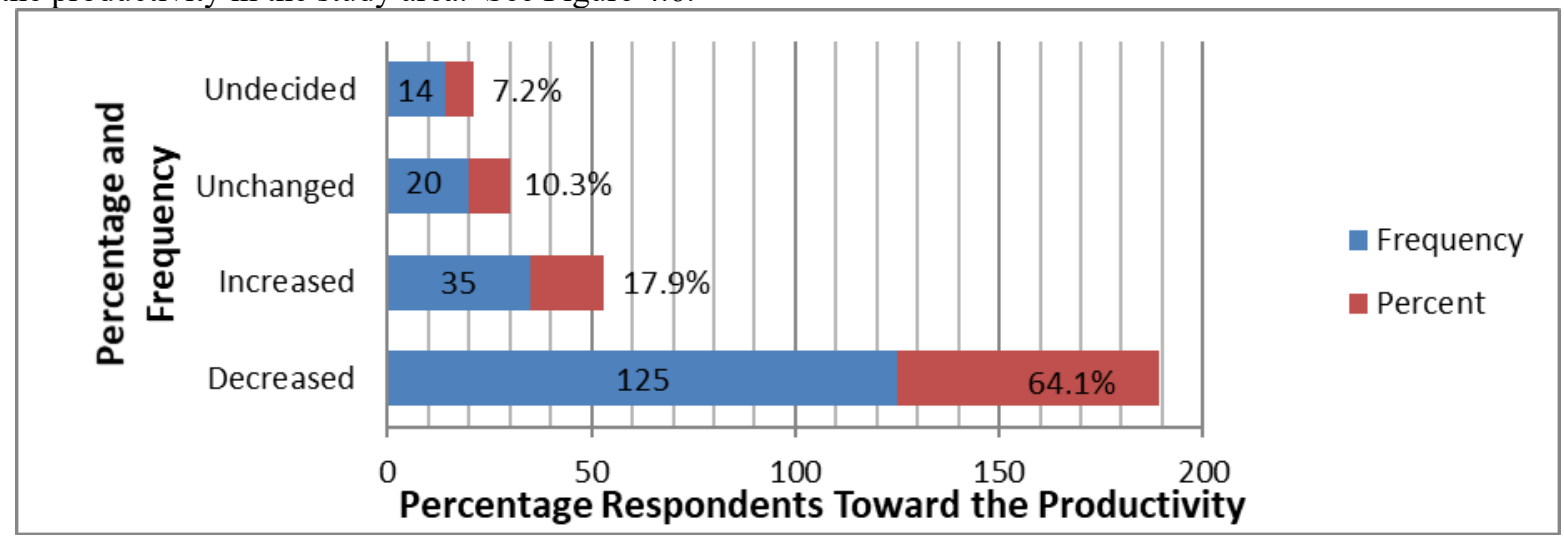

Figure 12. Showing percentage of the respondent toward the productivity

\subsection{The impacts of land use/land cover change on the land management}

Regarding to the effects of rapid changes in LU/LC on the land management, as the findings show that, $66.7 \%$ of the respondents agreed that changes in land use/land cover affect the land management, $24.6 \%$ replied disagree, while $8.7 \%$ of the respondents were not decided whether land use land cover change affect land management or not (Figure 13).

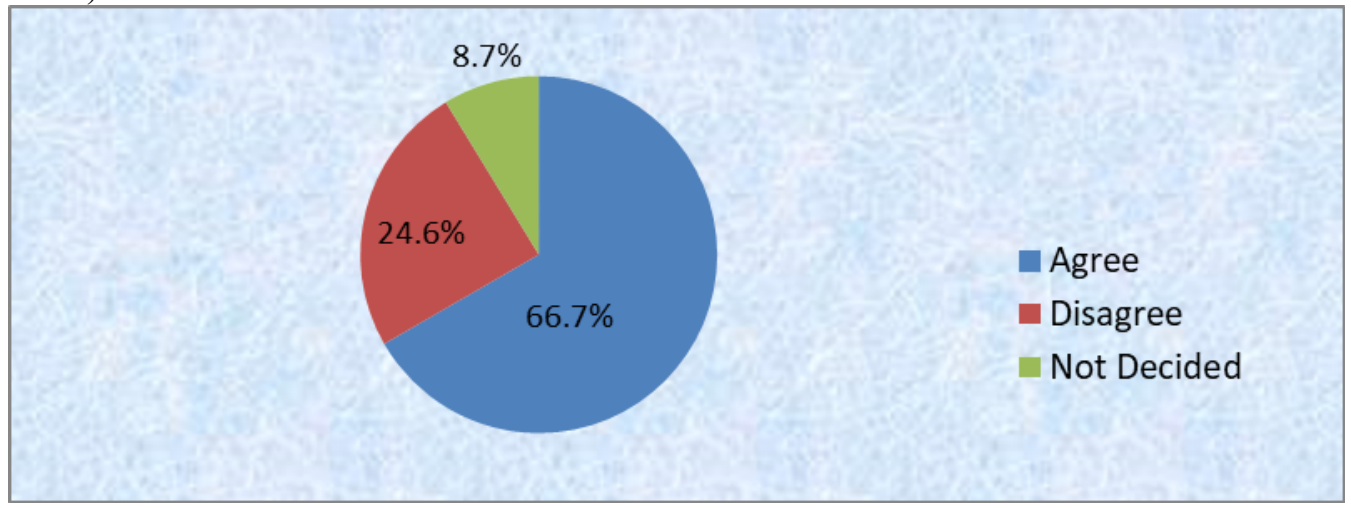

Figure 13. Perception of respondents regarding to the effects of LU/LC changes on the land management

Additionally, the respondents were also asked if agreed with its effects, the ways in which the land use land cover change affect the land management. In line with this, respondents state that change in LU/LC affect land management in terms of security of tenure and taxation, Environmental sustainability and land use planning.

\subsection{The impacts of LU/CC on the land management in terms of security of tenure and taxation}

Land management must be based on knowledge that depends on information and information depends on the data collection methods and the manner in which their results are communicated. Each nation must have good land records: of ownership to ensure security of tenure, of value to ensure fairness in land and property taxation and equity in the compulsory acquisition of land for state purposes and of the use of land to ensure efficient resource management and sustainability. 
The aim of the sustainable land management and use policy was to provide security of tenure for the farmers; however, change in the LU/LC in the study area is affect security of the tenure. Based on information obtained from participants, LU/LCC can be affecting the land management in term of tenure security and land taxation; for instance, when someone (the ownership of the property right) needs transaction of the land right, the process occurs (accomplished) at the kebele level and ownership certification book remained in the hands of former (seller of the property right), the buyer of the property right had not yet received certification book that describes the full information about that property, because of the transaction should not fulfilled legal procedures. In this regard, person who buys the right of occupation/use of the property become informal ownership, because he/she do not hold a certification book. All references to land and agreements between two parties in this guidance should not be taken at the woreda level. This indicates the legal document should not yet registered in the woreda land administration. In this regard, land management missed a corrected documentation. Land tax also has neither paid by buyer nor seller of the property right and thereby government income gain from land has been diminished. It has also caused for the emergence for the expansion of the informal settlement in the study area, in which the residential areas where the inhabitants with no have security of tenure, the land or dwellings they inhabit. In addition to this, the neighborhoods usually lack or are cut-off from basic services and city infrastructure and the housing may not comply with current planning and building regulations, therefore, a number of challenges to tenure security remained, as well as the land management is likely to be challenged, thereby, difficult to control such types of the problems in the current first level land certification. On the other hand, if the land use former may farmland, later (after transaction) it may be changed into settlement, in line with this, in the land management office, the current land use /land cover extents is not known due to fact that the documentation shows only the former owner of the property right. So, it is obvious that LU/LCC has tremendous problems which cannot be described in simple words. Therefore, a number of important impacts of the LU/LCC on land management in terms of tenure security and land taxation are summarized as;

* The Problem of identifying and correcting title belongs to a property right

* Problem related to government income from land tax

* The problem of controlling property of urban and rural land

\subsection{The impacts of LU/LCC on the land management in terms of land use planning}

Better land management and better land use can be encouraged through planning and development regulations. The application of the land management is capable to ensure land use planning both in rural and urban land use. However, the expansion of the informal settlement due to land use land cover change in the study area affects land management strategies in terms of land use planning.

As clearly indicated in the LU/LC dynamic analysis above Table 4.1 and Figure 4.1, the area under settlement showed a significant increase in the Adama Zuria District over the 28 years period (1989-2017). Besides, as evidenced from satellite imagery, other land use classes (shrub land and bare land) have decreased. The area coverage of shrub land and bare land has converted to the settlement. Figure 4.8 shows the expansion of the settlement between 1989 and 2017.

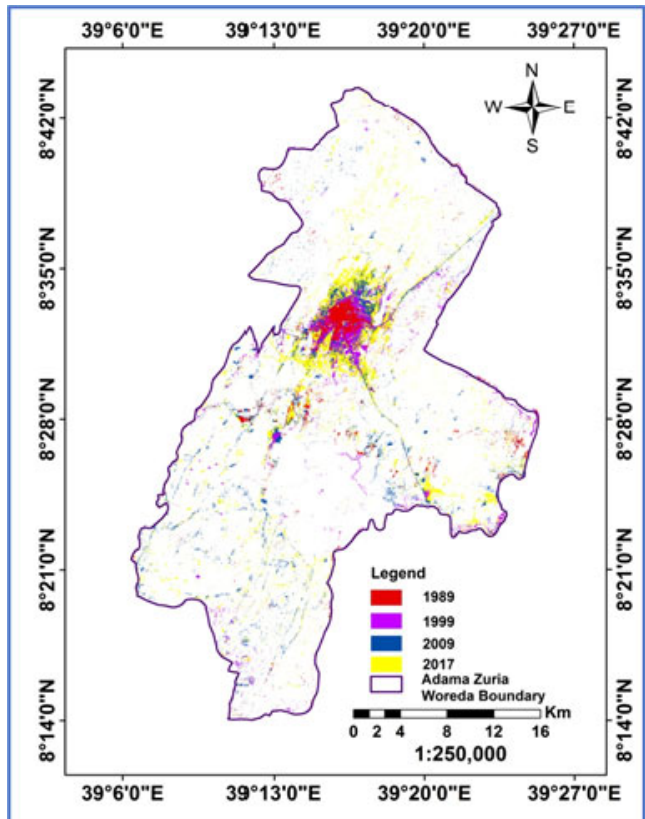

Figure 13. the distribution of the settlement in the Adama Zuria District 
In addition to this, the analysis also shows, the area coverage of farmland observed had changed in the year of 2017 (farm land has decreased between 2009 and 2017). The outskirts of the town and city in the study area, agricultural land has been converted to the settlements. During the time of the key informant interview, the respondents were asked the cause of the change in the patterns of the settlement: informal land transaction (farmland found at the edge of the city and town) and migration from rural to urban in the study area has been reported as the main cause for the issues. The settlers illegally purchased land from the holders of the land, meaning the local farmers. Farmers subdivided a plot of the farming area and sold that to the different squatters for housing purposes. The land that the settlers have settled was originally held by peasant farmers and the land use purpose was agriculture. There is shortage of land in the district and yet farmers are selling land illegally. The uncontrolled expansion of the human settlement leads to the conversation of the best agricultural land in to the settlement. Therefore, land use planning challenged to do with existing problems come up due to LU/LCC. With these regards, change in LU/LC hindering the planning regulation of the land use for the development purpose, in this case, the objective of the land management disturbed.

\subsection{The impacts LU/LCC on the land management in terms of environmental sustainability}

Efficient land management provides environmental sustainability. Sustainable natural resources (environment) are used for a variety of purposes which may include organic agriculture, reforestation, water resource management and eco-tourism projects. However, change in the land use land cover, such as decrease in the area coverage of the shrub land due to deforestation, over exploitation of trees and overgrazing (soil erosion) leads degradation of the land that affects environmental quality due to changes in the LU/LCC. Thus, the conversion of forest land to other type of land use caused numerous negative impacts on the ecosystem as well as the livelihood of the society in the study area. Similarly, the information obtained from FGD illustrate that the local people use energy source, like charcoals and wood from surrounding environment. Vegetated area of the woreda was deteriorated and thereby resulting in the loss of biodiversity. In this case the quality of the environment was not sustained as the result of that negative change in land use land cover (land degradation, soil erosion, and vegetation destruction).

\section{Conclusions}

The dynamics of land use land/cover during the period of analysis $(1989-2007)$ demonstrate profound changes involving an increase and decrease in patterns of the land use land cover. The pattern of LU/LCC in different categories shows variation during the study periods. RS and GIS analysis results showed the percentage of bare land and shrub land has shown a slight decrease from $9.27 \%$ to $4.57 \%$ and $21.30 \%$ to $11.41 \%$ respectively, from 1989 to 2017. A corresponding increase has been observed in plantations, settlement and farmland which have been increased from $7.85 \%$ to $8.97 \%, 0.83 \%$ to 6.23 and $60.44 \%$ to $68.47 \%$ respectively in the same period. The decrease in bare and shrub land partly reflects the considerable degradation of natural vegetation in the area and the expansion of the farmland.

The socio-economic survey conducted also revealed that the major cause of the land use/land cover change were population growth, land tenure insecurity, expansion of settlement, environmental problems and expansion of the infrastructure and social services. The effect of the land use/land cover change was the other concern of the study and the analysis of the survey indicates that the current problems associated with land use and land cover changes can be related partly to the livelihoods of the local population (socio-economic conditions) and land management Increase demand/population growths, deforestation, development of the infrastructure, transaction of the land, expansion of the formal and informal settlement were encountered as the root cause for the land use land cover change. The current population pressure has caused a high demand for additional land; as a result, the shortage of cultivated land is the major problem for farmers in the study area. Hence, the expansions of cultivated land into the marginal land lead to more severe land degradation. Agricultural expansion is one the major proximate or direct causes of LU/LCC in the study area. This implies that population pressure is believed to be one of the major driving forces for the change of LU/LC in the study area.

Land use-Land Cover has a significant impact on land management and tenure security. Overall, these changes affect the livelihoods of societies directly or indirectly. LULC dynamics are widespread, accelerating and significant processes majorly impelled by human actions and at the same time, resulting to changes, that impact human livelihood.

\section{REFERENCES}

Belay, E. (2009). Modeling Site Suitability for Wind Farm Using Remote Sensing and Gis. The Case of Adama Woreda.

Bonini, M., Corti, G., Innocenti, F., Manetti, P., Mazzarini, F., Abebe, T., and Pecskay, Z. (2005). "Evolution of the Main Ethiopian Rift in the frame of Afar and Kenya rifts propagation. Tectonics 24, TC1007.

Cleaver K, S. G. (1994). Reversing the spiral. The population, agriculture and environment nexus in sub-Saharan 
Africa. Directions in development. Washington (DC): The World Bank.

CSA (2014). Central Statistical Agency. Summary and Statistical Report of the Population and Housing Census.Addis Ababa, Ethiopia.

FAO (1984). World soil information from website: www.isric.org. Accessed on May, 2018.

FAO/UNEP. (1999). Terminology for integrated resources planning and management. F. a. a. o. U. N. E. program. Rome, Italy and Nairobi, Kenya.

Fu BJ, C. L., Ma KM, Zhou HF, Wang J (2000). The Relationships Between Land-Use and Soil conditions in the Hilly Area of the Loess Plateau in Borthern Shaanxi, China. Catena. 36: 6978.

Gebrekidan, W. (2016). Modeling land surface temperature from satellite data, the case of Addis Ababa. ES RI, Eastern Africa Education GIS conference. Held at Africa hall, United Nations Conference Center from 2324 Sept. 2016, Addis Ababa.

Lambin, E. F., Geist, H.J. and Lepers, E. (2003). "Dynamics of Landuse and Land cover change in Tropical Regions." Annu.Rev.Environ.Resour. 28:205-41.

Ramachandra, T. V., Aithal, B. H., and Sanna, D. (2012). "Land Surface Temperature Analysis in an Urbanizing Landscape Through Multi-Resolution Data." Research and Reviews: Journal of Space Science and Technology, 1(1), 1-10.

Reid RS, K. R., Muthui N, Taye A, Wotton S, Wilson CJ, Mulatu W (2000). "Land-Use and Land-Cover Dynamics in Response to Changes in Climatic, Biological and Socio-Political Forces:The case of southwestern Ethiopia." Landscape Ecol, 15: 339-355.

SC, M. (1996). "A partial instructional module on global and regional land use/cover change: assessing the data and searching for general relationships." Geo-Journal, 39(3):241-283. 